\title{
Mechanochemical Synthesis of Primary Amides
}

\author{
Jorge Gómez-Carpintero, J. Domingo Sánchez, J. Francisco González,* and J. Carlos Menéndez*
}

Cite This: J. Org. Chem. 2021, 86, 14232-14237

Read Online

ABSTRACT: Ball milling of aromatic, heteroaromatic, vinylic, and aliphatic esters with ethanol and calcium nitride afforded the corresponding primary amides in a transformation that was compatible with a variety of functional groups and maintained the integrity of a stereocenter $\alpha$ to carbonyl. This methodology was applied to $\alpha$-amino esters and $N$-BOC dipeptide esters and also to the synthesis of rufinamide, an antiepileptic drug.

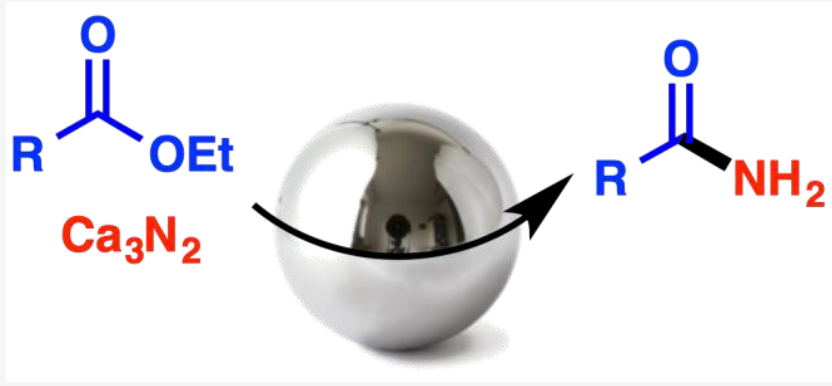

$\mathrm{M}$ echanochemistry involves chemical transformations induced by the direct absorption of mechanical energy, normally arising from grinding or milling processes. This mode of activation has grown in importance over the past decade, ${ }^{1}$ and indeed, in 2019 IUPAC chose mechanochemistry as one of the "ten chemical innovations that will change the world". Mechanochemistry is generally performed in the solid state and, therefore, under solvent-free conditions with very high reagent concentrations. Consequently, solvation phenomena are not significant, often leading to accelerated reactions and alterations in product selectivity, which may lead to the discovery of new chemical transformations. ${ }^{3}$ Furthermore, the use of solvent-free conditions is relevant in the context of green chemistry, since volatile organic solvents are the vast majority of residues from synthetic activities. ${ }^{4}$ Accordingly, there is a growing interest in the application of mechanochemistry to the synthesis of active pharmaceutical ingredients (APIs). ${ }^{5}$

The amide group is one of the most fundamental structural fragments in organic molecules. It is key to the primary structure of peptides and proteins, a group of biomolecules essential to life, and it is also widespread in polymers, agrochemicals, and drug molecules. Indeed, amide preparation is the most frequent chemical transformation in drug synthesis, and it has been estimated to comprise about $25 \%$ of the reactions performed in medicinal chemistry projects. ${ }^{6} \mathrm{~A}$ number of mechanochemical approaches to amide synthesis from amines and carboxylic acids have been developed on the basis of the use of coupling reagents such as EDC, ${ }^{7}$ EDC/ $\mathrm{HOBt}$ in the presence of $\mathrm{Mg}-\mathrm{Al}$ hydrotalcite, ${ }^{8} \mathrm{EDC}$ in the presence of nanocrystalline hydroxyapatite, ${ }^{9}$ carbonyldiimidazole, ${ }^{10}$ 2,4,6-trichloro-1,3,5-triazine/triphenylphosphine, ${ }^{11}$ uronium-based reagents, ${ }^{12}$ and hydrolytic enzymes. ${ }^{13}$ In polymer science, amide bonds have also been generated from acyl chlorides and anilines under mortar and pestle milling conditions $^{14}$ or ball milling. ${ }^{15} \mathrm{~N}$-Arylamides have been obtained from $O$-pivaloyl hydroxamic acids and aryl iodides or boronic acids under ball milling in the presence of a copper mediator. ${ }^{16}$ Mechanochemical versions of the Ritter reaction ${ }^{17}$ and the Beckmann rearrangement ${ }^{18}$ are also relevant routes to amides. For the case of peptide synthesis, direct coupling of amino acids with Leuchs anhydrides or $\mathrm{N}$-carboxyanhydrides, ${ }^{19}$ or the use of ethyl cyano(hydroxyimino)acetate (Oxyma) to promote the reaction between amino ester salts and $N$-protected amino acids, have been employed. ${ }^{20}$ Nevertheless, the synthesis of primary amides by mechanochemical methods has not been described so far, with the exception of the transformation of carboxylic acids into amides by manually grinding carbocylic acids, 2,4,6-trichloro-1,3,5-triazine, and ammonium thiocyanate in the presence of potassium carbonate, ${ }^{21}$ perhaps due to the difficulties found in handling gaseous reagents under ball milling. ${ }^{22}$ Our goal here is to offer a simple solution to this problem via a process for preparing primary amides from esters using calcium nitride as a source of ammonia. Primary amide groups are widespread in natural products and drug molecules, and some representative examples of the latter are shown in Figure 1.

We first optimized the mechanochemical transformation of ethyl 3-fluorobenzoate $\mathbf{1 a}$ into primary amide $\mathbf{2 a}$ with magnesium nitride, which has been employed as a source of ammonia in several transformations, although harsh reaction conditions were required (sealed tube, $80{ }^{\circ} \mathrm{C}, 24 \mathrm{~h}$ ). ${ }^{23}$ We first examined the reaction of $2 \mathrm{a}$ with magnesium nitride-ethanol in the absence of additives, but only starting materials were

Special Issue: Enabling Techniques for Organic Synthesis

Received: September 25, 2021

Published: October 1, 2021

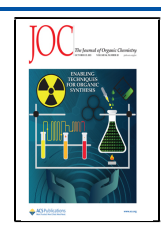


<smiles>NC(=O)c1cccnc1</smiles><smiles>NC(=O)CN1CCCC1=O</smiles>

Piracetam

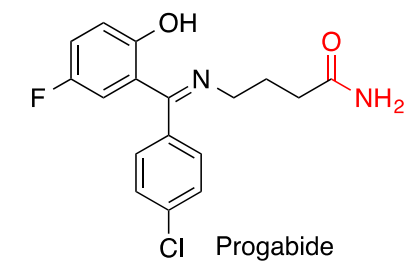

Figure 1. Representative drugs containing a primary amide group.

recovered at milling frequencies up to $30 \mathrm{~Hz}$ for 90 min using a stainless steel milling jar and ball (Table 1, entry 1). After

Table 1. Catalyst Optimization in the Synthesis of 2a<smiles>CCOC(=O)c1cccc(F)c1</smiles>

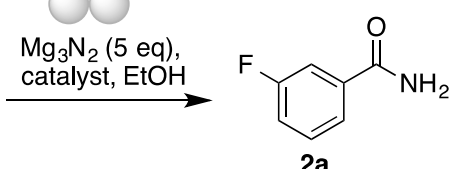

$\mathrm{Mg}_{3} \mathrm{~N}_{2}+6 \mathrm{EtOH} \longrightarrow 2 \mathrm{NH}_{3}+3 \mathrm{Mg}(\mathrm{OEt})_{2}$

\begin{tabular}{clccc} 
entry & catalyst (equiv) & $\begin{array}{c}\text { time } \\
(\mathrm{min})\end{array}$ & $\begin{array}{c}\text { frequency }^{a} \\
(\mathrm{~Hz})\end{array}$ & $\begin{array}{c}\text { conversion }^{b, c} \\
(\%)\end{array}$ \\
\hline 1 & & 90 & 30 & 0 \\
2 & $\mathrm{AlCl}_{3}(0.2)$ & 90 & 30 & 37 \\
3 & $\mathrm{Yb}(\mathrm{OTf})_{3}(0.2)$ & 90 & 30 & 28 \\
4 & $\mathrm{CuSO}_{4}(0.2)$ & 90 & 30 & 12 \\
5 & $\mathrm{CuBr}(0.2)$ & 90 & 30 & 67 \\
6 & $\mathrm{ZnCl}_{2}(0.2)$ & 90 & 30 & 85 \\
7 & $\mathrm{ZnCl}_{2}(0.2)$ & 60 & 30 & 52 \\
8 & $\mathrm{ZnCl}_{2}(0.1)$ & 90 & 30 & 43 \\
9 & $\mathrm{ZnCl}_{2}(0.1)$ & 90 & 25 & 37 \\
10 & $\mathrm{InCl}_{3}(0.2)$ & 90 & 30 & 91 \\
11 & $\mathrm{InCl}_{3}(0.2)$ & 60 & 30 & 86 \\
12 & $\mathrm{InCl}_{3}(0.2)$ & 60 & 25 & 83 \\
13 & $\mathrm{InCl}_{3}(0.1)$ & 60 & 25 & 23
\end{tabular}

${ }^{a}$ In a $10 \mathrm{~mL}$ stainless steel milling jar containing a single stainless steel ball $10 \mathrm{~mm}$ in diameter. ${ }^{b}$ Estimated by ${ }^{1} \mathrm{H}$ NMR analysis of the reaction crude, using 1,3,5-trimetoxybenzene as an internal standard. ${ }^{c} 5$ equiv of magnesium nitride and $1 \mathrm{~mL}$ of ethanol were employed. ${ }^{23 a}$

several Lewis acid catalysts were screened with moderate success (entries 2-5), zinc chloride ( 0.2 equiv, $90 \mathrm{~min}, 30 \mathrm{~Hz}$ ) gave a good $85 \%$ conversion (entry 6 ), although attempts to reduce reaction time, catalyst loading, or milling frequency were unsuccessful (entries 7-9). Indium trichloride was later identified as a better catalyst, allowing $91 \%$ conversion (entry $10)$, but again reductions in reaction time or milling frequency were slightly detrimental (entries 11 and 12) and a lower amount of catalyst was not tolerated (entry 13).

Starting from these conditions, the optimization of other reaction parameters was undertaken. Attempted purification of the crude reaction products by extraction with ethyl acetatewater, in spite of the excellent conversion, gave only $22 \%$ isolated yield (Table 2, entry 1). This was ascribed to interference of magnesium salts present in the reaction
Table 2. Optimization of Additional Reaction Parameters in the Synthesis of $2 a^{a}$

\begin{tabular}{|c|c|c|c|c|}
\hline entry & $\begin{array}{l}\text { catalyst } \\
\text { (equiv) }\end{array}$ & $\begin{array}{c}\text { ammonia source } \\
\text { (equiv) }\end{array}$ & proton source & $\begin{array}{c}\text { yield } \\
(\%)\end{array}$ \\
\hline 1 & $\mathrm{InCl}_{3}(0.2)$ & $\mathrm{Mg}_{3} \mathrm{~N}_{2}$ (5) & $\mathrm{EtOH}(1 \mathrm{~mL})$ & 23 \\
\hline 2 & $\mathrm{InCl}_{3}(0.2)$ & $\mathrm{NH}_{4} \mathrm{Cl}(5)$ & & 0 \\
\hline 3 & $\mathrm{InCl}_{3}(0.2)$ & $\mathrm{NH}_{4} \mathrm{OAc}(5)$ & & 0 \\
\hline 4 & $\mathrm{InCl}_{3}(0.2)$ & $\mathrm{Mg}_{3} \mathrm{~N}_{2}(2)$ & EtOH $(1 \mathrm{~mL})$ & traces \\
\hline 5 & $\mathrm{InCl}_{3}(0.3)$ & $\mathrm{Mg}_{3} \mathrm{~N}_{2}(2)$ & $\mathrm{EtOH}(1 \mathrm{~mL})$ & traces \\
\hline 6 & $\mathrm{InCl}_{3}(0.4)$ & $\mathrm{Mg}_{3} \mathrm{~N}_{2}$ (3) & $\mathrm{EtOH}(1 \mathrm{~mL})$ & 73 \\
\hline 7 & $\mathrm{InCl}_{3}(0.4)$ & $\mathrm{Mg}_{3} \mathrm{~N}_{2}$ (3) & EtOH (solvent) & $49^{b}$ \\
\hline 8 & $\mathrm{InCl}_{3}(0.4)$ & $\mathrm{Ca}_{3} \mathrm{~N}_{2}$ & EtOH $(1 \mathrm{~mL})$ & 10 \\
\hline 9 & $\mathrm{InCl}_{3}(0.4)$ & $\mathrm{Ca}_{3} \mathrm{~N}_{2}$ (3) & $\mathrm{EtOH}(1 \mathrm{~mL})$ & 79 \\
\hline 10 & $\mathrm{InCl}_{3}(0.4)$ & $\mathrm{Ca}_{3} \mathrm{~N}_{2}$ & EtOH $(0.5 \mathrm{~mL})$ & 83 \\
\hline 11 & $\mathrm{InCl}_{3}(0.4)$ & $\mathrm{Ca}_{3} \mathrm{~N}_{2}$ & EtOH $(0.3 \mathrm{~mL})$ & 88 \\
\hline
\end{tabular}

${ }^{a}$ All reactions were performed at $1 \mathrm{mmol}$ scale by ball milling (stainless steel jar and ball) at $30 \mathrm{~Hz}$ for $90 \mathrm{~min} .{ }^{b}$ Control experiment carried out in solution.

medium, which remain as a suspension during workup. We attempted the use of alternative sources of ammonia, such as ammonium chloride or acetate, but no product formation was observed (entries 2 and 3). Lowering the amount of magnesium nitride to 2 equiv was also unsuccessful (entries 4 and 5), but the use of 3 equiv of the ammonia source, coupled to an increase in the catalyst load, gave a promising $73 \%$ isolated yield (entry 6). In an effort to improve the isolation protocol, we performed workup with an aqueous solution of Rochelle salt, which often prevents the formation of emulsions in reactions involving aluminum-based reagents, but in our case, no improvement was observed. A control experiment carried out in solution, at room temperature, gave $49 \%$ isolated yield of compound $\mathbf{2 a}$, proving the beneficial effect of the mechanochemical conditions (entry 7). The use of calcium nitride was then assayed, with improved results (entries 8 and 9). Finally, we observed an additional improvement by lowering the amount of ethanol (entries 10 and 11), which can be ascribed to more efficient milling due to the smaller amount of liquid in the mixture.

Using the optimized conditions, we examined the scope of the mechanochemical protocol for the synthesis of primary amides. Our results are summarized in Scheme $2 \mathrm{a}$ and show that the method is suitable for the preparation of aromatic $(\mathbf{2 a}-\mathbf{c})$, heteroaromatic $(\mathbf{2 h}-\mathbf{j})$, vinylic $(\mathbf{2 d})$, aliphatic $(\mathbf{2 e}, \mathbf{f}$ and $2 \mathbf{k}-\mathbf{n})$, and aliphatic cyclic $(\mathbf{2 g})$ amides from the corresponding esters. Several functional groups, including halogen, acetal, thioether, and amino groups, were tolerated ( $2 \mathrm{a}, \mathbf{2 e}$, and $\mathbf{2 m}, \mathbf{n}$, respectively). It is also relevant to note that the stereogenic center of the amino acid esters maintained its integrity, as shown by the optical rotation of compound $2 \mathbf{m}$, identical to published values. The mechanochemical conditions were also employed to obtain dipeptide amides from the corresponding esters while maintaining the carbamate protection, affording compounds 2o-2q. A lactone, 3,4dihydrocoumarin $\mathbf{1 q}$, was also efficiently transformed into the corresponding hydroxy amide $2 \mathbf{q}$ (Scheme $2 \mathbf{b}$ ). A control experiment with benzoic acid did not furnish $\mathbf{2} \mathbf{b}$, giving instead recovered starting material.

Yields were generally in the $70-90 \%$ range and could be compared to those obtained under sealed-tube heating ${ }^{23 a}$ for three examples. In the case of $\mathbf{2} \mathbf{d}$ and $\mathbf{2 g}$, the mechanochemical yield was lower ( $74 \%$ vs $99 \%$ for $\mathbf{2 d}$ and $67 \%$ vs $85 \%$ for $\mathbf{2 g}$ ), 
Scheme 2. Scope of the Mechanochemical Primary Amide Synthesis

(a)

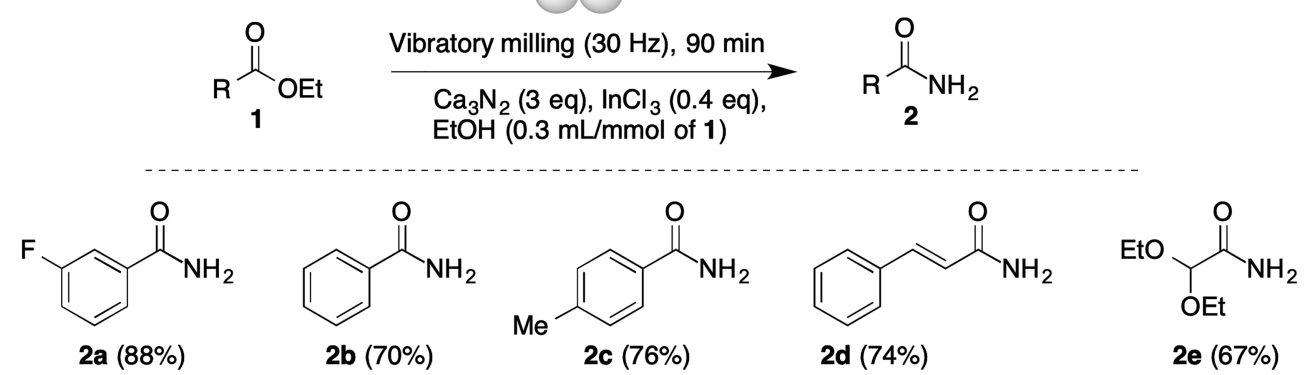<smiles>CCCCCCC(C)C(N)=O</smiles>

$2 f(68 \%)$<smiles>NC(=O)Cc1ccccc1</smiles>

2k (79\%)<smiles>NC(=O)C1CCCCC1</smiles>

2c $(76 \%)$

2d $(74 \%)$

2e $(67 \%)$<smiles>NC(=O)c1cccnc1</smiles>

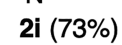<smiles>NC(=O)c1cccs1</smiles><smiles>[131In]</smiles><smiles>C=N[18OH]</smiles><smiles>NC(=O)CN1CCCCC1</smiles>
2l (60\%)<smiles>CC(C)(C)OC(=O)N[C@@H](Cc1c[nH]c2ccccc12)C(=O)NCC(N)=O</smiles><smiles>CC(C)(C)OC(=O)NC(Cc1ccccc1)C(=O)NCC(N)=O</smiles><smiles>CC(C)(C)C(Cc1ccccc1)C(N)=O</smiles><smiles>COCCC(N)C(N)=O</smiles>

(b)

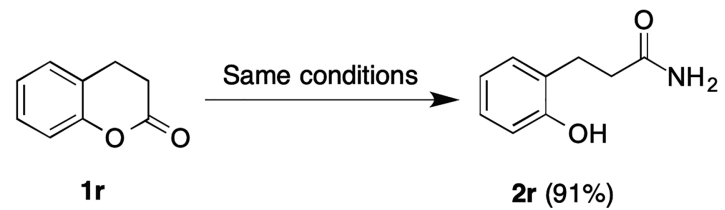

while 2 n gave a better yield under ball milling (91\% vs. $83 \%$ ). Importantly, the mechanochemical conditions were milder (no external heating vs $80^{\circ} \mathrm{C}$ ), reaction times were drastically shorter ( $90 \mathrm{~min}$ vs $24 \mathrm{~h}$ ), and solid-phase extraction through a hydrophobic frit $^{23 a}$ was not required for purification.

In order to show the applicability of the mechanochemical method to a multistep synthesis, we examined the preparation of the drug rufinamide, ${ }^{24}$ approved for the treatment of Lennox-Gastaut syndrome and other forms of epilepsy, by the route summarized in Scheme 3. The starting material 3 was transformed into azide 4 and then into the triazole-derived ester $\mathbf{5}$ using a literature procedure, ${ }^{25}$ and its mechanochemical treatment with calcium nitride under our optimal conditions afforded rufinamide (6) in $61 \%$ yield.

In conclusion, mechanochemical activation by mall milling is a suitable method for the transformation of esters into primary amides by reaction with calcium nitride that does not require chromatography. It is compatible with a variety of functional groups and a stereocenter adjacent to carbonyl and was applied to the synthesis of $N$-BOC dipeptide esters and the antiepileptic drug rufinamide.

\section{EXPERIMENTAL SECTION}

Caution! The use of magnesium nitride to transform esters into amides in methanol solution at $80{ }^{\circ} \mathrm{C}$ has been described to cause occasional

Scheme 3. Synthesis of the Antiepileptic Drug Rufinamide Using Mechanochemical Conditions for the Primary Amide Formation Step

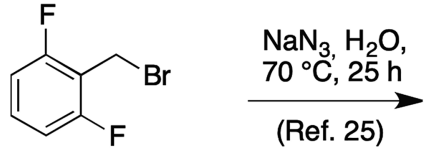

3

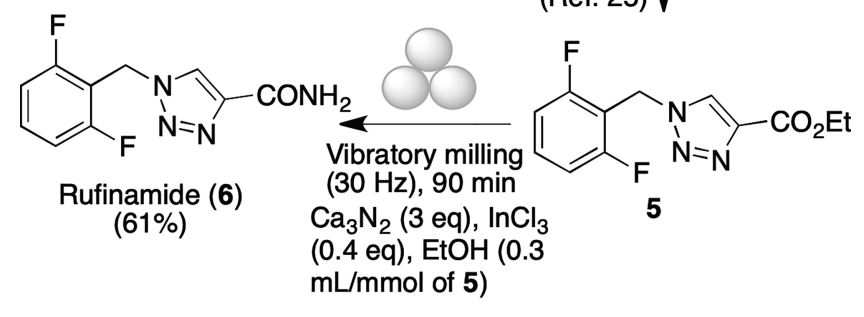

explosions, especially when working at a relatively large scale involving the use of $1.3 \mathrm{~g}$ of magnesium nitride and $6 \mathrm{~mL}$ of methanol; see the discussion in ref 37. We thank Duncan Browne (UCL School of Pharmacy) for bringing to our attention this safety issue and the associated references. Under our conditions (calcium nitride below 400 
$m g$, ethanol, ball milling in screw-top grinding jars) we have never observed any explosion.

General Experimental Information. All reagents and solvents were of commercial quality and were used as received. All compounds 1 were of commercial origin, with the exception of $1 \mathbf{o}-\mathbf{q}$, which were prepared using a literature method. ${ }^{26}$ Reactions were monitored by thin-layer chromatography on aluminum plates coated with silica gel and a fluorescent indicator. Mechanochemical reactions were performed in a mixer mill at a $30 \mathrm{~Hz}$ frequency, using a $10 \mathrm{~mL}$ stainless steel grinding jar and a single stainless steel ball $15 \mathrm{~mm}$ in diameter. Infrared spectra were recorded with a ATR spectrophotometer equipped with a diamond accessory. NMR spectra were recorded using spectrometers operating at $250 / 300 \mathrm{MHz}$ for ${ }^{1} \mathrm{H}$ NMR and $62.5 / 75 \mathrm{MHz}$ for ${ }^{13} \mathrm{C} \mathrm{NMR}$, maintained by the Nuclear Magnetic Resonance Unit at Universidad Complutense (UCM). Optical rotation values were determined with a polarimeter having a 1 $\mathrm{mL}$ cell and a sodium vapor lamp. Combustion elemental analyses were determined by the Elemental Microanalysis Unit (UCM).

General Procedure for the Mechanochemical Synthesis of Primary Amides. The suitable ester $(1 \mathrm{mmol})$, together with $\mathrm{Ca}_{3} \mathrm{~N}_{2}$ (445 mg, $3 \mathrm{mmol}), \mathrm{InCl}_{3}(88 \mathrm{mg}, 0.4 \mathrm{mmol})$, and ethanol $(0.3 \mathrm{~mL})$, were added to a $10 \mathrm{~mL}$ stainless steel milling jar, along with a $10 \mathrm{~mm}$ stainless steel ball. The ball mill was set to vibrate at a frequency of 30 $\mathrm{Hz}$ for $90 \mathrm{~min}$. Subsequently, the contents of the milling jar were washed twice with ethyl acetate $(5 \mathrm{~mL})$ and water $(2 \mathrm{~mL})$, and the two layers were separated. The aqueous layer was extracted with ethyl acetate $(2 \times 5 \mathrm{~mL})$, and the combined organic fractions were dried with $\mathrm{Na}_{2} \mathrm{SO}_{4}$ and concentrated under vacuum. The resulting solid was washed with petroleum ether $(2 \times 2.5 \mathrm{~mL})$ to afford the pure amides. The compounds thus obtained, including $\mathbf{2 a}-\mathbf{2 c},{ }^{27} \mathbf{2 d}, \mathbf{2 g}$ and $\mathbf{2 r}$, ${ }^{23 a}$ $\mathbf{2 e},^{28} \mathbf{2} \mathbf{f}^{29} \mathbf{2 h}$ and $\mathbf{2 j},{ }^{30} \mathbf{2 i},^{31} \mathbf{2 k},,^{32} \mathbf{2} \mathbf{l}^{33}$ and $\mathbf{6}^{34}$ showed characterization data coincident with those found in the literature, and copies of their NMR spectra can be found in the Supporting Information.

(+)-Phenylalaninamide (2m). ${ }^{1} \mathrm{H}$ NMR (300 MHz, methanol- $\left.d_{4}\right)$ : $\delta 7.35-7.19(\mathrm{~m}, 5 \mathrm{H}), 3.63-3.53(\mathrm{~m}, 1 \mathrm{H}), 3.04(\mathrm{dd}, J=13.4,5.9 \mathrm{~Hz}$, $1 \mathrm{H}), 2.81(\mathrm{dd}, J=13.4,7.6 \mathrm{~Hz}, 1 \mathrm{H}) .{ }^{13} \mathrm{C}\left\{{ }^{1} \mathrm{H}\right\}$ NMR $(75 \mathrm{MHz}$, methanol- $\left.d_{4}\right): \delta 178.1,137.5,129.1,128.2,126.4,56.0,41.1 .[\alpha]_{\mathrm{D}}{ }^{25}=$ $+22.4\left(0.02 \mathrm{~g} / 100 \mathrm{~mL}, \mathrm{H}_{2} \mathrm{O}+3\right.$ drops of $\left.35 \% \mathrm{HCl}\right)\left[\right.$ lit. $^{35}=+20.0$ (for the hydrochloride salt, $2 \mathrm{~g} / 100 \mathrm{~mL}, \mathrm{H}_{2} \mathrm{O}$ )].

$(+)$-Methionamide $(\mathbf{2 n})$. Spectral data were coincident with those found in the literature. ${ }^{36}[\alpha]_{\mathrm{D}}{ }^{25}\left(0.005 \mathrm{~g} / 100 \mathrm{~mL}, \mathrm{H}_{2} \mathrm{O}+3\right.$ drops of $35 \% \mathrm{HCl})=+6.6$.

(S)-tert-Butyl (1-((2-Amino-2-oxoethyl)amino)-3-(1H-indol-3-yl)1-oxopropan-2-yl)carbamate (2o). IR: 3296, 3066, 2976, $1655 \mathrm{~cm}^{-1}$. ${ }^{1} \mathrm{H}$ NMR $\left(250 \mathrm{MHz}, \mathrm{CDCl}_{3}\right) \delta 9.00(\mathrm{br} \mathrm{s}, 1 \mathrm{H}), 7.57(\mathrm{~d}, J=7.7 \mathrm{~Hz}$, $1 \mathrm{H}), 7.31(\mathrm{~d}, J=8.6 \mathrm{~Hz}, 1 \mathrm{H}), 7.19-7.03(\mathrm{~m}, 3 \mathrm{H}), 6.99(\mathrm{~s}, 1 \mathrm{H}), 6.42$ (br s, $1 \mathrm{H}), 6.25(\mathrm{br} \mathrm{s}, 1 \mathrm{H}), 5.58(\mathrm{br} \mathrm{s}, 1 \mathrm{H}), 4.44(\mathrm{q}, J=6.5 \mathrm{~Hz}, 1 \mathrm{H})$ 3.62 (br s, $2 \mathrm{H}), 1.39(\mathrm{~s}, 9 \mathrm{H}) .{ }^{13} \mathrm{C}\left\{{ }^{1} \mathrm{H}\right\} \operatorname{NMR}\left(62.5 \mathrm{MHz}, \mathrm{CDCl}_{3}\right) \delta$ 173.4, 172.8, 156.4, 136.7, 127.7, 124.1, 122.5, 119.94, 118.9, 112.0, $110.1,81.0,56.1,43.0,28.7$ ppm. $[\alpha]_{\mathrm{D}}^{25}=+6.16(c=0.006 \mathrm{~g} / 100$ $\mathrm{mL}, \mathrm{CHCl}_{3}$ ). Anal. Calcd for $\mathrm{C}_{18} \mathrm{H}_{24} \mathrm{~N}_{4} \mathrm{O}_{4}, \mathrm{C}, 59.99 ; \mathrm{H}, 6.71 ; \mathrm{N}$, 15.55. Found: C, 59.72; H, 6.59; N, 15.31 .

(S)-tert-Butyl (1-((2-Amino-2-oxoethyl)amino)-1-oxo-3-phenylpropan-2-yl)carbamate (2p). IR: 3298, 3072, 2977, $1664 \mathrm{~cm}^{-1} .{ }^{1} \mathrm{H}$ NMR $\left(250 \mathrm{MHz}, \mathrm{CDCl}_{3}\right.$, major conformer) $\delta 7.36-7.21(\mathrm{~m}, 5 \mathrm{H})$, 7.07 (br s, $1 \mathrm{H}, \mathrm{NH}), 6.53($ br s, $1 \mathrm{H}), 5.90($ br s, $1 \mathrm{H}), 5.31$ (br s, $1 \mathrm{H})$, $4.37(\mathrm{q}, 1 \mathrm{H}, J=7.0 \mathrm{~Hz}), 3.88(\mathrm{~m}, 2 \mathrm{H}), 3.08(\mathrm{~m}, 2 \mathrm{H}), 1.37(\mathrm{~s}, 9 \mathrm{H})$ ppm. ${ }^{13} \mathrm{C}\left\{{ }^{1} \mathrm{H}\right\}$ NMR $\left(62.5 \mathrm{MHz}, \mathrm{CDCl}_{3}\right) \delta 172.6,1721,156.3,136.8$, $129.6,129.2,127.5,81.1,56.7,43.1,38.4,28.6$ ppm. $[\alpha]_{\mathrm{D}}^{25}=+1.37(\mathrm{c}$ $=0.006 \mathrm{~g} / 100 \mathrm{~mL}, \mathrm{CHCl}_{3}$ ). Anal. Calcd for $\mathrm{C}_{16} \mathrm{H}_{23} \mathrm{~N}_{3} \mathrm{O}_{4}, \mathrm{C}, 59.80$; $\mathrm{H}, 7.21 ; \mathrm{N}, 13.08$. Found: C, 59.45; H, 7.02; N, 12.79.

(S)-tert-Butyl (1-((2-Amino-2-oxoethyl)amino)-1-oxopropan-2yl)carbamate (2q). IR: 3297, 2977, $1656 \mathrm{~cm}^{-1} \cdot{ }^{1} \mathrm{H}$ NMR (250 $\mathrm{MHz}, \mathrm{CDCl}_{3}$ major conformer) $\delta 7.48(\mathrm{br} \mathrm{t}, J=5.0 \mathrm{~Hz}, 1 \mathrm{H}), 6.95(\mathrm{br}$ s, $1 \mathrm{H}), 6.26($ br s, $1 \mathrm{H}), 5.55($ br d, $J=5.0 \mathrm{~Hz}, 1 \mathrm{H}), 4.18(\mathrm{~m}, 1 \mathrm{H})$, $4.00(\mathrm{dd}, 2 \mathrm{H}, J=17.0$ and $5.5 \mathrm{~Hz}), 1.44(\mathrm{~s}, 9 \mathrm{H}), 1.38(\mathrm{~d}, 3 \mathrm{H}, J=7.0$ $\mathrm{Hz}) \mathrm{ppm} .{ }^{13} \mathrm{C}\left\{{ }^{1} \mathrm{H}\right\}$ NMR $\left(62.5 \mathrm{MHz}, \mathrm{CDCl}_{3}\right) \delta 174.2,172.6,156.4$, 80.9, 51.1, 43.1, 28.7, and $18.3 \mathrm{ppm} .[\alpha]_{\mathrm{D}}{ }^{25}=-11.25(c=0.004 \mathrm{~g} /$
$100 \mathrm{~mL}, \mathrm{CHCl}_{3}$ ). Anal. Calcd for $\mathrm{C}_{10} \mathrm{H}_{19} \mathrm{~N}_{3} \mathrm{O}_{4}: \mathrm{C}, 48.97 ; \mathrm{H}, 7.81 ; \mathrm{N}$, 17.13. Found: C, 48.68; H, 7.62; N, 16.97 .

\section{ASSOCIATED CONTENT}

Supporting Information

The Supporting Information is available free of charge at https://pubs.acs.org/doi/10.1021/acs.joc.1c02350.

Copies of ${ }^{1} \mathrm{H}$ NMR and ${ }^{13} \mathrm{C}\left\{{ }^{1} \mathrm{H}\right\}$ NMR spectra of all compounds (PDF)

\section{AUTHOR INFORMATION}

\section{Corresponding Authors}

J. Francisco González - Unidad de Química Orgánica y Farmacéutica, Departamento de Química en Ciencias Farmacéuticas, Facultad de Farmacia, Universidad Complutense, 28040 Madrid, Spain; Email: jfgonzal@ ucm.es

J. Carlos Menéndez - Unidad de Química Orgánica y Farmacéutica, Departamento de Química en Ciencias Farmacéuticas, Facultad de Farmacia, Universidad Complutense, 28040 Madrid, Spain; orcid.org/00000002-0560-8416; Email: josecm@ucm.es

\section{Authors}

Jorge Gómez-Carpintero - Unidad de Química Orgánica y Farmacéutica, Departamento de Química en Ciencias Farmacéuticas, Facultad de Farmacia, Universidad Complutense, 28040 Madrid, Spain

J. Domingo Sánchez - Unidad de Química Orgánica y Farmacéutica, Departamento de Química en Ciencias Farmacéuticas, Facultad de Farmacia, Universidad Complutense, 28040 Madrid, Spain

Complete contact information is available at: https://pubs.acs.org/10.1021/acs.joc.1c02350

\section{Notes}

The authors declare no competing financial interest.

\section{ACKNOWLEDGMENTS}

Support from Ministerio de Ciencia e Innovación (Grant No. RTI2018-097662-B-I00) and Universidad Complutense (predoctoral contract to JG-C) is gratefully acknowledged. We also acknowledge the COST Action CA18112 (Mechanochemistry for Sustainable Industry).

\section{REFERENCES}

(1) For selected recent reviews, see: (a) O’Neill, R. T.; Boulatov, R. The many flavours of mechanochemistry and its plausible conceptual underpinnings. Nat. Chem. Rev. 2021, 5, 148-167. (b) Egorov, I. N.; Santra, S.; Kopchuk, D. S.; Kovalev, I. S.; Zyryanov, G. V.; Majee, A.; Ranu, B. C.; Rusinov, V. L.; Chupakhin, O. N. Ball-milling: An efficient and green approach for asymmetric organic synthesis. Green Chem. 2020, 22, 302-315. (c) Friščić, T.; Mottillo, C.; Titi, H. M. Mechanochemistry for synthesis. Angew. Chem., Int. Ed. 2020, 59, 1018-1029. (d) Porcheddu, A.; Colacino, E.; De Luca, L.; Delogu, F. Metal-mediated and metal-catalyzed reactions under mechanochemical conditions. ACS Catal. 2020, 10, 8344-8394. (e) Howard, J. L.; Cao, Q.; Browne, D. L. Mechanochemistry as an emerging tool for molecular synthesis: what can it offer? Chem. Sci. 2018, 9, 30803094. (f) Leonardi, M.; Villacampa, M.; Menéndez, J. C. Multicomponent mechanochemical synthesis. Chem. Sci. 2018, 9, 20422064. (g) See also refs 3-5.

(2) (a) Gomollón-Bel, F. Ten chemical innovations that will change our world. Chem. Int. 2019, 41, 12-17. (b) Krämer, K. https://www. 
chemistryworld.com/news/iupac-names-10-chemistry-innovationsthat-will-change-the-world/3010335.article.

(3) Hernández, J. C.; Bolm, C. Altering product selectivity by mechanochemistry. J. Org. Chem. 2017, 82, 4007-4019.

(4) Ardila-Fierro, K. J.; Hernández, J. G. Sustainability assessment of mechanochemistry by using the twelve principles of green chemistry. ChemSusChem 2021, 14, 2145-2162.

(5) For reviews, see: (a) Tan, D.; Loots, L.; Friščić, T. Towards medicinal mechanochemistry: evolution of milling from pharmaceutical solid form screening to the synthesis of active pharmaceutical ingredients (APIs). Chem. Commun. 2016, 52, 7760-7781. (b) PérezVenegas, M.; Juaristi, E. Mechanochemical and mechanoenzymatic synthesis of pharmacologically active compounds: A green perspective. ACS Sustainable Chem. Eng. 2020, 8, 8881-8893. (c) Ying, P.; $\mathrm{Yu}, \mathrm{J}$.; Su, W. Liquid-assisted grinding mechanochemistry in the synthesis of pharmaceuticals. Adv. Synth. Catal. 2021, 363, 12461271.

(6) Boström, J.; Brown, D. G.; Young, R. J.; Keserü, G. M. Expanding the medicinal chemistry synthetic toolbox. Nat. Rev. Drug Discovery 2018, 17, 709-727.

(7) Strukil, V.; Bartolec, B.; Portada, T.; Đilović, I.; Halasz, I.; Margetic, D. One-pot mechanosynthesis of aromatic amides and dipeptides from carboxylic acids and amines. Chem. Commun. 2012, 48, 12100-12102.

(8) Landeros, J. M.; Juaristi, E. Mechanochemical synthesis of dipeptides using $\mathrm{Mg}$-Al hydrotalcite as activating agent under solventfree reaction conditions. Eur. J. Org. Chem. 2017, 687-694.

(9) Anselmi, M.; Stavole, P.; Boanini, E.; Bigi, A.; Juaristi, E.; Gentilucci, L. Green synthesis of bioactive oligopeptides promoted by recyclable nanocrystalline hydroxyapatite. Future Med. Chem. 2020, 12, 479-491.

(10) Kumar, V.; Kumar Giri, S.; Venugopalan, P.; Ravindranathan Kartha, K. P. Synthesis of cross-linked glycopeptides and ureas by a mechanochemical, solvent-free reaction and determination of their structural properties by TEM and X-ray crystallography. ChemPlusChem 2014, 79, 1605-1613.

(11) Duangkamol, C.; Jaita, S.; Wangngae, S.; Phakhodee, W.; Pattarawarapan, M. An efficient mechanochemical synthesis of amides and dipeptides using 2,4,6-trichloro-1,3,5-triazine and $\mathrm{PPh}_{3}$. RSC Adv. 2015, 5, 52624-52628.

(12) Dalidovich, T.; Mishra, K. A.; Shalima, T.; Kudrjasǒva, M.; Kananovich, D. G.; Aav, R. Mechanochemical synthesis of amides with uronium-based coupling reagents: A method for hexa-amidation of biotin[6]uril. ACS Sustainable Chem. Eng. 2020, 8, 15703-15715.

(13) (a) Hernández, J. G.; Ardila-Fierro, K. J.; Crawford, D.; James, S. L.; Bolm, C. Mechanoenzymatic peptide and amide bond formation. Green Chem. 2017, 19, 2620-2625. (b) Bolm, C.; Hernández, J. G. From synthesis of amino acids and peptides to enzymatic catalysis: A bottom-up approach in mechanochemistry. ChemSusChem 2018, 11, 1410-1420.

(14) Rajput, L.; Banerjee, R. Mechanochemical synthesis of amide functionalized porous organic polymers. Cryst. Growth Des. 2014, 14, 2729-2732.

(15) Yang, Y.; Bu, F.; Liu, J.; Shakir, I.; Xu, Y. Mechanochemical synthesis of two-dimensional aromatic polyamides. Chem. Commun. 2017, 53, 7481-7484.

(16) Broumidis, E.; Jones, M. C.; Vilela, F.; Lloyd, G. O. Mechanochemical synthesis of $\mathrm{N}$-aryl amides from $\mathrm{O}$-protected hydroxamic acids. ChemPlusChem 2020, 85, 1754-1761.

(17) Dokli, I.; Gredičak, M. Mechanochemical Ritter reaction: A rapid approach to functionalized amides at room temperature. Eur. J. Org. Chem. 2015, 2727-2732.

(18) Mocci, R.; Colacino, E.; De Luca, L.; Fattuoni, C.; Porcheddu, A.; Delogu, F. The mechanochemical Beckmann rearrangement: An eco-efficient "cut-and-paste" strategy to design the "good old amide bond". ACS Sustainable Chem. Eng. 2021, 9, 2100-2114.

(19) (a) Declerck, V.; Nun, P.; Martinez, J.; Lamaty, F. Solvent-free synthesis of peptides. Angew. Chem., Int. Ed. 2009, 48, 9318-9321. (b) Hernández, J. G.; Juaristi, E. Green synthesis of $\alpha, \beta$ - and $\beta, \beta$ - dipeptides under solvent-free conditions. J. Org. Chem. 2010, 75, 7107-7111. (c) Bonnamour, J.; Métro, T.-X.; Martinez, J.; Lamaty, F. Environmentally benign peptide synthesis using liquid-assisted ballmilling: application to the synthesis of Leu-enkephalin. Green Chem. 2013, 15, 1116-1110.

(20) (a) Porte, V.; Thioloy, M.; Pigoux, T.; Métro, T.-J.; Martinez, J.; Lamaty, F. Peptide mechanosynthesis by direct coupling of $N$ protected $\alpha$-amino acids with amino esters. Eur. J. Org. Chem. 2016, 3505-3508. (b) Maurin, O.; Verdié, P.; Subra, G.; Lamaty, F.; Martinez, J.; Métro, T.-J. Peptide synthesis: ball-milling, in solution, or on solid support, what is the best strategy? Beilstein J. Org. Chem. 2017, 13, 2087-2093.

(21) Jaita, S.; Phakhodee, W.; Chairungsi, N.; Pattarawarapan, M. Mechanochemical synthesis of primary amides from carboxylic acids using TCT $/ \mathrm{NH}_{4} \mathrm{SCN}$. Tetrahedron Lett. 2018, 59, 3571-3573.

(22) Bolm, C.; Hernández, J. G. Mechanochemistry of gaseous reactants. Angew. Chem., Int. Ed. 2019, 58, 3285-3299.

(23) (a) Veitch, G. E.; Bridgwood, K. L.; Ley, S. V. Magnesium nitride as a convenient source of ammonia: Preparation of primary amides. Org. Lett. 2008, 10, 3623-3625. (b) Bridgwood, K. L.; Veitch, G. E.; Ley, S. V. Magnesium nitride as a convenient source of ammonia: Preparation of dihydropyridines. Org. Lett. 2008, 10, 3627-3629. (c) Veitch, G. E.; Bridgwood, K. L.; Rands-Trevor, K.; Ley, S. V. Magnesium nitride as a convenient source of ammonia: Preparation of pyrroles. Synlett 2008, 2008, 2597-2600.

(24) Padmaja, R. D.; Chanda, K. A short review on synthetic advances toward the synthesis of rufinamide, an antiepileptic drug. Org. Process Res. Dev. 2018, 22, 457-466.

(25) Kankan, R. N.; Rao, D. R.; Birari, D. R. Process for the preparation of rufinamide. PCT/GB2009/002419, 2009-09-10.

(26) López-Cobeñas, A.; Cledera, P.; Sánchez, J. D.; LópezAlvarado, P.; Ramos, M. T.; Avendaño, C.; Menéndez, J. C. Microwave-assisted synthesis of 2,5-piperazinediones under solventfree conditions. Synthesis 2005, 19, 3412-3422.

(27) Li, X.-G.; Wang, W.-K.; Han, Y.-X.; Zhang, C. One-pot synthesis of symmetrical 1,3-diarylureas or substituted benzamides directly from benzylic primary alcohols and effective oxidation of secondary alcohols to ketones using phenyliodine diacetate in combination with sodium azide. Adv. Synth. Catal. 2010, 352, $2588-2598$.

(28) Chiacchio, U.; Rescifina, A.; Saita, M. G.; Iannazzo, D.; Romeo, G.; Mates, J. A.; Tejero, T.; Merino, P. Zinc(II) triflate-controlled 1,3dipolar cycloadditions of C-(2-thiazolyl)nitrones: Application to the synthesis of a novel isoxazolidinyl analogue of tiazofurin. J. Org. Chem. 2005, 70, 8991-9001.

(29) Lambert, D. M.; Vandevoorde, S.; Diependaele, G.; Govaerts, S. J.; Robert, A. R. Anticonvulsant activity of N-palmitoylethanolamide, a putative endocannabinoid, in mice. Epilepsia 2001, 42, 321-327.

(30) Xu, F.; Song, Y.-Y.; Li, Y.-J.; Li, E.-L.; Wang, X.-R.; Li, W.-Y.; Liu, C.-S. An efficient protocol for the synthesis of primary amides via Rh-catalyzed rearrangement of aldoximes. ChemistrySelect 2018, 3, 3474-3478.

(31) Ray, R.; Hazari, A. S.; Chandra, S.; Maiti, D.; Lahiri, G. K. Highly selective ruthenium-catalyzed direct oxygenation of amines to amides. Chem. - Eur. J. 2018, 24, 1067-1071.

(32) Tinnis, F.; Lundberg, H.; Adolfsson, H. Direct catalytic formation of primary and tertiary amides from non-activated carboxylic acids, employing carbamates as amine source. Adv. Synth. Catal. 2012, 354, 2531-2536.

(33) Khalil, A.; Elsayed, G. A.; Mohamed, H. A.; Raafat, A. Utility of chloroacetonitrile in construction of some hitherto novel pyrazole and thiazole derivatives. J. Iran. Chem. Soc. 2018, 15, 191-199.

(34) Meena, D. R.; Rao, R. N.; Maiti, B.; Chanda, K. Novel Cu(I)catalyzed one-pot multicomponent synthesis of the antiepileptic drug rufinamide. Res. Chem. Intermed. 2017, 43, 4711-4717.

(35) Smith, E. L.; Spackman, D. H. Leucine aminopeptidases V. Activation, specificity and mechanism of action. J. Biol. Chem. 1955, $212,271-299$ 
(36) Aguiar, R. M.; Leao, R. A. C.; Mata, A.; Cantillo, D.; Kappe, C. O.; Miranda, L. S. M.; de Souza, R. O. M. A. Continuous-flow protocol for the synthesis of enantiomerically pure intermediates of anti epilepsy and anti tuberculosis active pharmaceutical ingredients. Org. Biomol. Chem. 2019, 17, 1552-1557.

(37) (a) Crane, S. Chem. Eng. News 2009, 87 (15), 2-4. (b) Ley, S. V. Chem. Eng. News 2009, 87 (23), 4-5. (c) Buske, G. Chem. Eng. News 2009, 87 (28), 2-4.

\section{NOTE ADDED AFTER ASAP PUBLICATION}

Published ASAP on October 1, 2021; Safety statement and ref 37 added October 6, 2021. 